\title{
O espaço livre público informal como lócus da oportunidade e da integração socioespacial da cidade: o caso da favela Beira Molhada, em João Pessoa - PB, Brasil
}

Informal public open space as locus of the opportunity and of social-spatial integration of city: the case of the Beira Molhada slum, in João Pessoa, Paraíba - Brazil

Yasmin Ramos Peregrino ${ }^{[0]}$, Ana Laura Rosas Brito ${ }^{[a]}$, José Augusto Ribeiro Silveira ${ }^{[b]}$

[a] Universidade Federal da Paraíba (UFPB), Programa de Pós-graduação em Arquitetura e Urbanismo, João Pessoa, PB, Brasil [b] Universidade Federal da Paraíba (UFPB), Laboratório do Ambiente Urbano e Edificado (LAURBE), João Pessoa, PB, Brasil

\section{Resumo}

Os espaços livres públicos são fundamentais às cidades, como lócus onde a sociedade pode criar e recriar a vida pública. Assim, objetiva-se investigar a produção desses espaços nas favelas para, através de conceitos como "direito à cidade", "retorno à cidade", acessibilidade, mobilidade, e das implicações da fragmentação e segregação, promover a integração socioespacial à cidade. 0 objeto empírico é a favela "Beira Molhada", em João Pessoa, Paraíba, dada a sua inserção na área periurbana e de preservação ambiental de beira d'água, com amplos espaços livres públicos. A metodologia compõe-se por pesquisa bibliográfica, documental, mapas mentais e analíticos georreferenciados. Os resultados apontam um tecido pouco relacionado à cidade e bens ambientais sob ameaça. Entretanto, há grande potencial para a integração socioespacial da favela à cidade, por meio do incentivo de uma dinâmica social mais rica facultando acessibilidade e mobilidade ao patrimônio ambiental e à sua fruição, contribuindo para o estabelecimento de uma 'sociedade urbana', como demonstrado por Lefebvre.

Palavras-chave: Favela. Espaços livres públicos. Integração socioespacial.

\section{Abstract}

Public open spaces are key to cities, as a place where society can create and recreate public life. Thus, we aim to investigate the production of these areas in slums through concepts such as "right to the city", "return to the city", accessibility, mobility, and the implications of fragmentation and segregation, in promoting the socio-integration into the city. The empirical object is the "Beira Molhada" slum in João Pessoa, Paraíba, because of its inclusion in peri-urban area and of environmental preservation, with large public open spaces. The methodology consists of literature and documentary research, mental maps and geo-referenced analyticals. The results indicate an issue poorly related with city and environmental goods under threat. However, there is great potential for socio-spatial integration of the slum with the city, by encouraging social dynamic that provides accessibility and mobility to the environmental heritage and its fruition, contributing to the establishment of an "urban society" as stated by Lefebvre.

Keywords: Slums. Open public spaces. Social-spatial integration.

YRP é arquiteta e urbanista, mestre em Arquitetura e Urbanismo, e-mail: yasminperegrino@gmail.com ALRB é arquiteta e urbanista, mestre em Arquitetura e Urbanismo, e-mail: analaura.brito@gmail.com JARS é arquiteto e urbanista, doutor em Desenvolvimento Urbano, e-mail: ct.laurbe@gmail.com 


\section{Introdução}

Os dados sempre crescentes acerca da quantidade de pessoas vivendo em assentamentos informais ao redor do mundo são dignos de atenção, visto que já são mais de 863 milhões de pessoas morando em condições subnormais de habitação, equivalente a um terço da população nas regiões em desenvolvimento (ONU \& PNDU, 2014). Ou seja, vivem em habitações construídas com materiais não duráveis, com acomodações superlotadas, sem acesso à água, saneamento ou segurança contra expulsões, e ajudam a configurar um ciclo de vida imerso na "vulnerabilidade"1, cercado de riscos que ameaçam o desenvolvimento humano (ONU \& PNDU, 2014).

A rápida urbanização e crescimento urbano sem planejamento favorecem o espraiamento e a fragmentação urbanas, e contribuem para enfraquecer o desenvolvimento das forças humanas, sobretudo em países de economias emergentes, sendo o Brasil um recorde em cidades fragmentadas, pois que

[...] o padrão de colcha de retalhos de nosso tecido urbano é o elemento que mais decisivamente colabora para a construção de um espaço de fragmentação, a comprometer as qualidades de percepção e apreensão ao se tornar menos acessível e permeável. São agravados, portanto, os estados de segregação espacial e derivados distanciamento entre ricos e pobres, dificuldade de locomoção, concentração de renda, baixa produtividade, etc. (Medeiros, 2014, p. 561).

Além disso, Davis (2006) destaca que não raro as favelas e demais espaços informais ${ }^{2}$ são tratados como locais de nulidades e de falta de vida. Entretanto, é notada uma vitalidade urbana latente de forças de superação contra as adversidades, quando os habitantes desses assentamentos precários adquirem coesão

\footnotetext{
${ }^{1} \mathrm{O}$ termo 'vulnerabilidade' empregado pelo Programa das Nações Unidas para o Desenvolvimento (PNUD) significa a exposição e a fragilidade social adquiridas desde o nascimento, quando as pessoas são expostas a situações de pobreza. Oposto à vulnerabilidade, tem-se, no mesmo relatório, o termo 'resiliência', que traz o entendimento sobre como superar os riscos sociais, sejam esses provenientes de fatores econômicos ou de base cultural, em busca de um desenvolvimento humano mais consistente.

${ }^{2}$ Leia-se cortiços, loteamentos irregulares, conjuntos habitacionais favelizados, etc.
}

social, ativam estratégias de empreendedorismo e cooperativismo, refletindo em melhorias socioespaciais, e, nesse sentido, a ação de diversos agentes sociais é decisiva para essa transformação.

Nesse contexto, ressalta-se o "direito à cidade"3, que, do ponto de vista lefebvriano, aponta que, para um projeto de "sociedade urbana", é preciso contar também com essa população segregada, vista como componente-chave no processo de transformação do espaço urbano, pois o "direito à cidade" se confunde com o "direito à vida" e se opõe à segregação. Diante disso, ações eficientes para a conquista de um espaço intraurbano mais democrático devem considerar que esses espaços segregados corroboram para a constituição de uma sociedade urbana heterogênea, e que "[...] o urbano não é indiferente a todas as diferenças, pois ele precisamente as reúne" (Lefebvre, 2004, p. 111).

$\mathrm{O}$ desengajamento dos organismos públicos e as incertezas e disparidades geradas pela economia global dão sinais de intensificação dos desafios a serem superados, inclusive, no que diz respeito à complexidade dos territórios informais a serem agregados aos tecidos urbanos, exigindo que os instrumentos de intervenção sejam reformulados em prol do "retorno à cidade" (Panerai, 1994). 0 mesmo autor destaca a primazia do "espaço público" ${ }^{4}$, visto que são decisivos no traçado urbano, pois recebem a rede de serviços funcionando como uma "sutura" aos tecidos urbanos (Panerai, 1994). Os conceitos de "direito à cidade" e "retorno à cidade" são decisivos para a construção de um espaço intraurbano humanizado, para todos, pois cada cidadão é um membro "natural" do todo urbano e não de partes específicas.

Assim, a humanização das cidades através de seus espaços públicos formais e informais permeia este artigo, em seu aporte teórico e na análise do objeto empírico, favela ${ }^{5}$ Beira Molhada, designada por seus moradores como "Três Lagoas", localizada na borda sudoeste da cidade de João Pessoa (PB). Busca-se, portanto, investigar a produção do ELP informal, suas implicações morfológicas e de apropriação, levando em conta

\footnotetext{
${ }^{3}$ Sobre o termo ler Lefebvre (2006) e Fioravante (2013).

${ }^{4}$ Panerai (1994) utiliza o termo 'espaço do público' significando espaço aberto e acessível a todos, a todo momento e aberto à coletividade, o qual deve ser encarado como domínio público.

${ }^{5}$ Aqui, optou-se por utilizar o termo favela conforme conceituado, sob uma ótica multidisciplinar, pelo Observatório das Favelas, em sua publicação “0 que é favela, afinal?” (Silva et al., 2009).
} 
as questões referentes à fragmentação, segregação, acessibilidade e mobilidade, em prol da integração socioespacial ao restante da cidade. A metodologia utilizada compôs-se das seguintes ferramentas mapas mentais, levantamentos fotográficos seriados e mapas georreferenciados. As considerações finais indicam caminhos para atitudes mais holísticas no âmbito da administração pública, bem como no da população civil, buscando a integração socioespacial das populações e dos tecidos urbanos notoriamente segregados.

\section{Os espaços livres públicos: virtudes e efeitos no urbano}

Os espaços intraurbanos podem ser divididos inicialmente em duas grandes categorias - espaços edificados e espaços livres, sendo esses últimos estabelecidos em dois âmbitos - público e privado -, podendo ser produzidos de modo formal ou informal. Assim, os espaços livres públicos (ELPs) englobam muito mais que áreas verdes, mas todo o espaço livre existente entre o construído, tais como vias, esplanadas, orlas, etc., configurando-se em elementos importantes da estrutura e da paisagem urbana (Queiroga, 2011). Além disso, associam-se à ideia de acessibilidade, lazer e conservação de recursos naturais, e são o lócus da manifestação cotidiana, das convivências e copresenças dos habitantes e do enfretamento dos conflitos (Leite, 2011; Magnoli, 2006).

Contudo, os ELPs não são comumente planejados como um sistema amplamente público, muitos não são interligados ou acessíveis, apresentando deficiências projetuais e paisagísticas (Macedo \& Custódio, 2009). No Brasil, esses espaços carecem de maior conexão física, estando seus componentes fragmentados e dispersos no tecido urbano, porém ainda possuem o potencial de articular-se em um grande sistema benéfico e democrático. Um sistema de ELPs adequado pode conter espaços privados que, articulados e qualificados, atendem às demandas de circulação e acesso de pedestres; acesso e estacionamento de veículos; áreas de estar, convívio, trabalho e preservação ambiental (Fontes \& Shimbo, 2003).
Assim, quando devidamente planejados, executados, apropriados $^{6}$ e geridos, os ELPs contribuem para a estruturação e integração urbana, auxiliando o equilíbrio ambiental, organizando a morfologia urbana e fornecendo os espaços necessários às interações sociais, políticas e culturais. Nesse sentido, destaca-se a possibilidade de um "sistema de sistemas" que pode abarcar da escala intraurbana à escala regional, devendo estar conectadas entre si, principalmente pelo sistema viário. Portanto, a produção de ELPs deve estar vinculada às demandas de diferentes públicos, e as atividades relacionadas à gestão e ao planejamento são de suma importância para o seu processo de consolidação de uso, apropriação e periódica observação das novas necessidades emergentes, tendo em vista as dinâmicas sociais ao longo do tempo (Pizzol, 2005). Compreender as tipologias espaciais desses espaços é fundamental para a sua integração (Quadro 1).

Espaços livres formais, como praças, parques, ruas, calçadões, são implantados segundo a legislação urbanística vigente, mas outros elementos podem surgir dessas mesmas ações públicas, sendo denominados de espaços colaterais, os quais seriam "resíduos de espaços" de obras de urbanização e implementação de infraestrutura, a exemplo de áreas abaixo de passagens elevadas e viadutos. Podem ainda ser denominados espaços não tratados ou acidentais, que podem ser lotes vazios ou certos alargamentos da estrutura urbana que passam a ser apropriados e podendo tornar-se o lócus para expressões socioculturais de uma determinada comunidade. Assim, as ações sobre o espaço e as consequentes transformações da forma urbana podem ser divididas em formais e informais, e a quantidade de espaços livres informais, residuais e colaterais existentes no tecido urbano pode ser um indicador da falta de políticas públicas (Custódio et al., 2013).

As diferentes tipologias e formas de produção dos ELPs levam às mais variadas práticas de apropriação, devendo-se buscar, sempre que possível, a multiplicidade de uso desses espaços. Por exemplo, uma quadra de esportes pode servir tanto para atividades físicas como para manifestações culturais, religiosas e políticas.

${ }^{6}$ Lefebvre (2006, p. 143) observa que "apropriação" é uma ação que se distingue do "direito à propriedade", pois significa muito mais o "[...] direito à vida urbana, à centralidade renovada, aos locais de encontro e de trocas, aos ritmos de vida e empregos do tempo que permitem o uso pleno e inteiro desses momentos e locais". 
Quadro 1 - Tipologia dos espaços livres públicos e privados

\begin{tabular}{|c|c|c|c|}
\hline \multicolumn{4}{|c|}{ ESPAÇOS LIVRES } \\
\hline \multicolumn{2}{|c|}{ ESPAÇOS LIVRES PÚBLICOS } & \multicolumn{2}{|c|}{ ESPAÇOS LIVRES PRIVADOS } \\
\hline \multicolumn{2}{|c|}{ Aqueles de posse e domínio público } & \multicolumn{2}{|c|}{$\begin{array}{l}\text { Aqueles de posse privada seja para uso misto, residencial, comercial, servicico e/ou } \\
\text { institucional, ou com concessão para uso público. }\end{array}$} \\
\hline URBANIZADO & LIVRES DE URBANIZAC̣̃̃O & $\begin{array}{l}\text { ESPAC̣OS DE SOLO NÃO } \\
\text { PERMEÁVEL }\end{array}$ & ESPAC̣OS DE SOLO PERMEÁVEL \\
\hline $\begin{array}{l}\text { Praças, parques urbanos, ruas, largos, } \\
\text { becos, calcadas, canteiros centrais, } \\
\text { calçadões, etc. }\end{array}$ & $\begin{array}{l}\text { Terras do poder público em geral, terras } \\
\text { devolutas, áreas de marinha, parques } \\
\text { nacionais, etc. }\end{array}$ & $\begin{array}{l}\text { Estacionamentos, pátios de carga e } \\
\text { descarga, terracosos, quadras poliesportivas } \\
\text { de condomínios habitacionais, etc. }\end{array}$ & Jardins, quintais, etc. \\
\hline
\end{tabular}

Fonte: Baseado em Barcelos apud Calderón (2009), Queiroga (2011), Macedo \& Custódio (2009).

A consolidação do uso e apropriação, por sua vez, pode variar em função de diversos aspectos, tais como: demanda dos diversos grupos sociais; clima e sua sazonalidade; entorno edificado; presença ou não de determinados equipamentos e condições de segurança (Queiroga, 2011).

Diante da diversidade de tipologias e apropriações dos ELPs, observa-se que não deve prevalecer um padrão homogêneo, visto que o urbano é, acima de tudo, heterogêneo do ponto de vista social, político e econômico. Nesse panorama, torna-se indispensável considerar a relação dos ELPs com a acessibilidade e a mobilidade, tendo em vista sua função de ligação e manutenção de um sistema, bem como quando restringidas influenciam diretamente nas questões de segregação e na criação de barreiras urbanas. Silveira et al. (2007) destacam que o sistema viário, como parte dos ELPs de circulação, compõe a infraestrutura com diferentes classificações quanto à hierarquia e a localização, tal como a sua posição na malha urbana, morfologia, condições operacionais, etc. Nesse contexto, a acessibilidade engloba basicamente três escalas territoriais interligadas: (i) Macroacessibilidade: possibilidade de atravessamento da cidade como um todo; (ii) Mesoacessibilidade: escala funcional intermediária de ligação entre setores urbanos, ou intrassetorial, ou ainda entre áreas - bairros e vias principais e/ou coletoras; (iii) Microacessibilidade: de ligação direta a pontos locais da cidade.

Deve-se considerar ainda a acessibilidade como aquela condição com a qual o espaço público deve ser provido para proporcionar o livre e amplo deslocamento a qualquer indivíduo. Assim, as barreiras devem ser consideradas como impeditivas do amplo uso público, tornando-se também barreiras socioeconômicas e culturais, sejam essas físicas ou impalpáveis, tais como sinalizações que não podem ser compreendidas por analfabetos, estrangeiros ou pessoas com deficiência (Pizzol, 2005). A mobilidade. que por sua vez significa a possibilidade de deslocamentos de pessoas e bens a todas as atividades cotidianas, é diretamente dependente da acessibilidade e deve ser entendida como um fenômeno multifacetado, de ação nos níveis social, econômico e político, que estabelece relações com as desigualdades sociais e a segregação (Vasconcelos, 2004; Silveira et al., 2007).

As possibilidades de mobilidade disponíveis em determinada área ou cidade influenciam na qualidade dos ELPs e seu público usuário, podendo ser uma ferramenta de exclusão ou integração social. Assim, os diferentes meios de transporte, nos diversos modais ${ }^{7}$, devem ser orquestrados em conjunto, essencialmente dando prioridade ao pedestre e articulando, de maneira sustentável e hierarquizada, meios de transporte coletivos. Ao pensar a mobilidade urbana buscando incorporar fatores econômicos, sociais, de limitação física, será produzida uma cidade mais integrada e que reduza consideravelmente a necessidade de infraestrutura e os altos gastos com mobilidade urbana (CREA-PR, 2011).

\footnotetext{
${ }^{7}$ Modais de transporte são meios pelos quais os veículos de transporte de passageiros e cargas podem utilizar, sendo mais comuns no Brasil, por ordem de maior uso, os tipos: Rodoviário, Ferroviário, Aquaviário, Dutoviário e Aéreo. No meio urbano e para a transporte de passageiros, tem-se os meios de transporte a pé, carro, bicicleta, moto, ônibus municipal, ônibus metropolitano e trilhos. Fonte: CREA-PR (2011).
} 
Nesse sentido, a investigação dos ELPs de uma cidade e sua capacidade de prover acessibilidade e mobilidade traz importantes informações para as estratégias de planejamento e gestão, isso porque o caráter mais significativo do espaço não está na função que se determina para ele em projeto, mas sim na capacidade em ser vital, materializada nas possibilidades de apropriação que ele oferece aos indivíduos. Além disso, o ELP possui uma amplitude maior que aquela do "espaço público" geralmente considerado, pois assim se incluem as fachadas dos edifícios e tudo que pode ser visto ao nível dos olhos. Desse modo, tem-se o espaço público, o privado e as chamadas zonas híbridas, consideradas também como semipúblicas ou semiprivadas (Figura 1).

Ao compreender o ELP nesse contexto, é possível observar sua relação com a arquitetura da cidade e até com a vida privada, pois que o tratamento projetual das zonas híbridas constitui uma ponte que pode corroborar ou não para a transição entre o público e o privado. Tal transição, quando bem-sucedida, pode contribuir para a vida pública ou, quando malsucedida, pode implicar insegurança, isolamento, falta de relação entre os habitantes e o espaço público e até mesmo o esvaziamento desse. Jacobs (2011) alerta sobre a importância das conexões visuais e possibilidades de acessos entre as zonas públicas e privadas, pois através dessas conexões surgem as possibilidades de filtrar e graduar os níveis de intimidade desejados entre ambas as áreas. Quando acesso visual entre as fachadas e o exterior é fomentado, chega-se a ter "os olhos das ruas", como cita a autora, quando os residentes, através de monitoração e vigilância naturais, fortalecem os laços com o espaço público.

Acerca disso, Gehl (2014) e Karssenberg et al. (2015) apresentam a necessidade de abordar o caso do fortalecimento das áreas públicas mediante o reconhecimento e atuações nos ambientes privados e híbridos, no que nem sempre é possível descrever legalmente e intervir projetivamente nos espaços de transição, pois suas delimitações conceituais e práticas são pouco claras ou ambíguas. Entretanto, é notória a importância de se intensificar as atividades e possibilidades dos espaços de transição e integrar às zonas privada e pública. Além disso, deve-se atentar para o fato de que várias situações de conflito podem surgir, desde responsabilidades de manutenção, acessibilidade, quebra da privatização por parte de terceiros ou a apropriação indevida de áreas públicas pelo privado.

Veremos que essas ambiguidades e responsabilidades em relação aos espaços de transição são bem mais complexas quando se trata dos ELPs Informais, pois costumam diferir do tecido formal por apresentar escalas de publicização específicas e, comumente, apropriações mais efetivas dos espaços públicos, podendo implicar positiva e/ou negativamente na qualidade de vida de seus habitantes. Santos (1985) indica que o espaço intraurbano é diretamente influenciado por forças dinâmicas que transformam o meio urbano constantemente, contribuindo ou prejudicando a vitalidade dos ELPs, criando novos fixos e fluxos.

Quanto à publicização, no contexto dos assentamentos precários/favelas, as "zonas híbridas" ou "de transição"

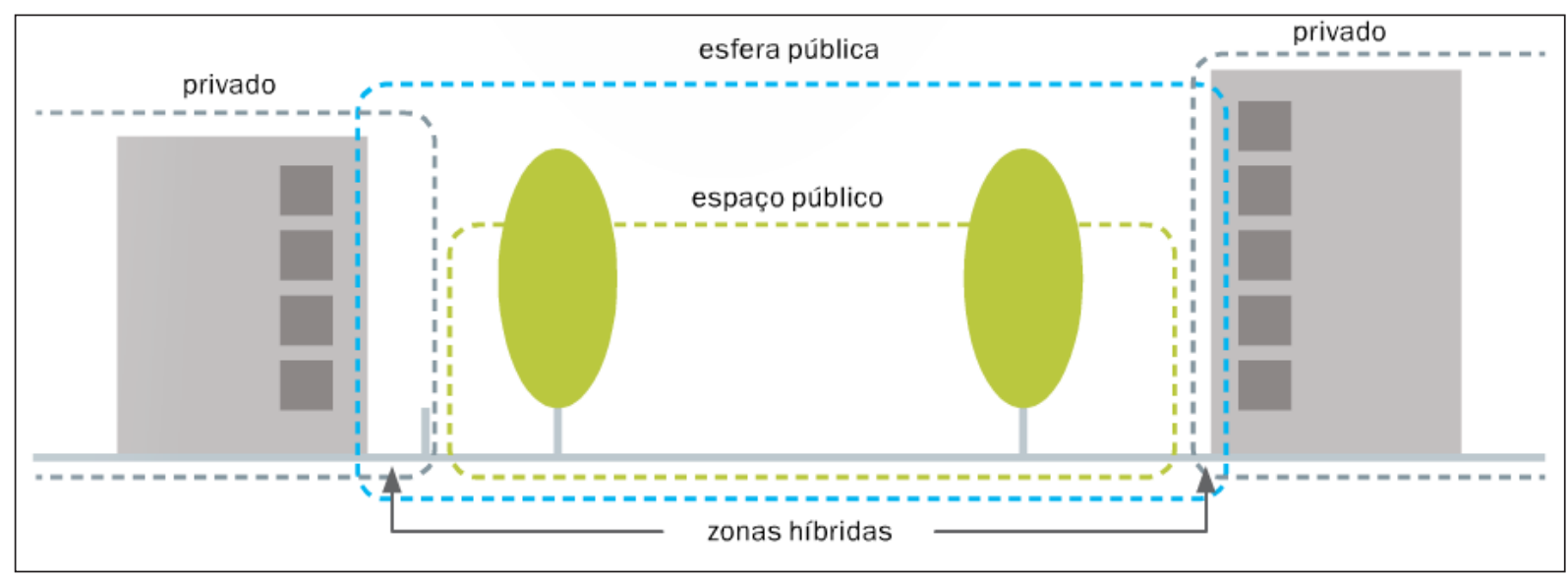

Figura 1 - Esquema esfera pública e espaços públicos e privados Fonte: Karssenberg et al. $(2015$, p. 15). 
são frequentes, pois o tecido urbano complexo e denso fortalece o senso de vizinhança, por intermédio do qual a esfera privada frequentemente se estende até a pública por causa da proximidade das moradias e o subdimensionamento das vias, criando espaços de sociabilidade (Karssenberg et al., 2015). Os espaços públicos e privados são intrinsecamente ligados por escalas intermediárias de publicização, onde as ruelas são vistas como continuação das casas e tornam-se espaços semiprivados, ao passo que a maioria dos terraços das casas pode constituir espaços semipúblicos. É essa influência mútua "meio-indivíduo" que nos permite destacar e abordar os espaços livres da favela em suas partes físicas, como sendo casa e rua (DaMatta, 1997, p. 25-26).

Além do caráter físico do ELP da favela, é importante mencionar que as relações sociais (fluxos) são fundamentais para o estabelecimento da morfologia urbana (fixos) característica desses assentamentos, embora o contrário também ocorra, como cita DaMatta (1997). Assim, a configuração física desses espaços viabiliza muitos dos comportamentos sociais, possibilitando uma dinâmica socioespacial intensa na construção do espaço físico e, muitas vezes, supera a temporalidade da produção do espaço urbano formal.

Mesmo diante de tal hierarquização e distanciamento social entre o tecido formal e o informal, convém perceber que a identificação, correção ou manutenção dos ELPs nas favelas e das práticas sociais neles desenvolvidas são de grande importância para o estudo do fenômeno urbano como um todo, visto que a produção formal e a informal devam estar conectadas, no sentido de evitar a segregação e a fragmentação urbana. Entretanto, percebe-se que as políticas públicas que deveriam dar suporte a tal integração, diversas vezes posicionam-se contrariamente à reintegração da parcela informal, mostrando-se ineficientes mesmo diante de tantos avanços alcançados em matéria de infraestrutura básica e serviços públicos essenciais.

Por outro lado, é possível encontrar exemplos positivos de planejamento urbano espontâneo feito por moradores, de acordo com suas necessidades e contribuindo para a vitalidade do ELP informal. Nesse sentido, uma das especificidades do espaço urbano da favela reside na diversidade de usos, texturas e padrões espaciais, além da dinâmica que faz com que "[...] as construções numa favela - e [...] a própria favela - jamais ficam de todo concluídas [...]" (Jacques, 2011, p. 28). Assim, a percepção espacial do
ELP da favela dificilmente é previsível ou monótona, mas sim mutável e dinâmica.

Ainda que a urgência de abrigo conduza, sobretudo, ao uso residencial, a favela costuma contar com diversidade de usos, entre serviços e comércio que complementam a renda familiar e funcionam como atratores de pessoas, contribuindo para a vitalidade do espaço público. Além disso, a malha urbana apresenta uma intrincada trama familiar de seus residentes, pois esses ampliam as habitações à medida que os filhos nascem, sendo constantes as invasões aos espaços livres públicos para dar lugar a novos cômodos, a novas casas ou mesmo ampliações para uso comercial. Esse fazer, sem planejamento projetual prévio, embora possua seu valor socioespacial, é complicado também por riscos ambientais e sociais - pelo pouco ou nenhum acesso à infraestrutura necessária à qualidade de vida, tais como habitabilidade, saneamento, água, energia elétrica e tantos outros, sendo resultado direto da segregação socioespacial que se materializa na diferenciação de acesso aos serviços básicos

Lefebvre (2006) comenta que os indivíduos deveriam ter as mesmas oportunidades de se beneficiarem dos diversos aspectos da vida urbana, todavia, este conceito ideal é infringido em diversos âmbitos internos à favela. No tocante aos espaços públicos, que deveriam oferecer a possibilidade de ir e vir sem necessidade de justificar o propósito da presença no local específico, por vezes é tolhido do cotidiano das favelas, principalmente quando há domínio de milícia e de tráfico de drogas, ou de policiamento oficial despreparado para lidar com o cidadão. Acerca disso, embora as favelas pertençam inerentemente aos moradores, os traficantes e forças policiais têm um efeito abrangente sobre a liberdade do público de desfrutar do espaço (Dixon, 2014, p. 5).

Embora todas estas problemáticas resultantes da falta de infraestrutura, da segregação socioespacial e da violência impliquem dificuldades de acesso e permanência, isso não determina ELPs sem uso na favela, que, ao contrário, permanecem predominantemente ativos. A falta de atenção, por parte da gestão pública, no que se refere à manutenção e uso já consolidados destes espaços, gera entraves na solução dos problemas de infraestrutura, na mobilidade interna à favela e na acessibilidade que contribuiria para a integração do espaço urbano como um todo.

Nesse sentido, vale ressaltar a ação de agências sociais, tais como líderes e associações comunitárias, 
igrejas, ONGs, grupos de pesquisa e suporte técnico mantidos por universidades, os quais têm o poder de servir de mediadores nas comunidades e reaver o caráter público dos espaços livres. Tais entidades passam a conhecer mais a fundo a identidade socioespacial da localidade e proporcionam inúmeras iniciativas de dinâmicas sociais benéficas à maioria da população, podendo dar suporte substancial a políticas públicas de planejamento. Vale ainda destacar que, por mais problemas que as populações de assentamentos informais enfrentem, é notória a ideia de que suas comunidades são ainda o 'lugar da oportunidade', onde se pode melhorar social e economicamente através do trabalho pessoal e colaborativo ${ }^{8}$.

Assim, estratégias de suporte para superação dessas condições são observadas em níveis de planejamento global, mas também local, através de intervenções de pequena escala, a exemplo das acupunturas urbanas ${ }^{9}$, que são intervenções de menor escala, de baixo custo

${ }^{8}$ Burdett (2012) traz relatos importantes sobre assentamentos informais ao redor do mundo, destacadamente em países da América Latina, África e Ásia, e ressalta exatamente que esses habitantes têm, através dos anos, construído e melhorado suas comunidades investindo no desenvolvimento de seus ambientes locais apoiadas por agências sociais.

${ }^{9}$ Acerca do termo 'acupuntura urbana', consultar Lerner (2003) e Sola-Morales (2008). e que podem ser replicadas pela comunidade ou em outras comunidades. Burdett (2012) destaca algumas dessas ações, geradoras de impactos positivos nas comunidades, tais como ações que ocupam áreas vazias ou prédios abandonados reformados com materiais de baixo custo e temporários, materializadas no estabelecimento de sedes comunitárias que abrigam creches, cozinhas coletivas, suporte à maternidade, atividades esportivas e educacionais, etc. Essas atitudes, que num contexto mais amplo podem parecer simplórias, têm apresentado êxito em torno da superação das problemáticas sociais e seus impactos às gerações subsequentes.

\section{O caso de Beira Molhada}

A favela 'Beira Molhada', popularmente conhecida como "Três Lagoas", está localizada entre o Açude das Três Lagoas e as rodovias BR-101 e BR-230, no bairro Jardim Veneza, em João Pessoa, Paraíba, Brasil (Figura 2). 0 objeto empírico é oficialmente delimitado pela prefeitura como favela e Zona Espacial de Interesse Social (ZEIS), mas, visando uma análise integrada do objeto, foram feitas alterações em seu perímetro oficial, a saber: alguns lotes internos ao perímetro oficial foram desconsiderados, dada sua diferenciação morfológica (é notório o traçado formal

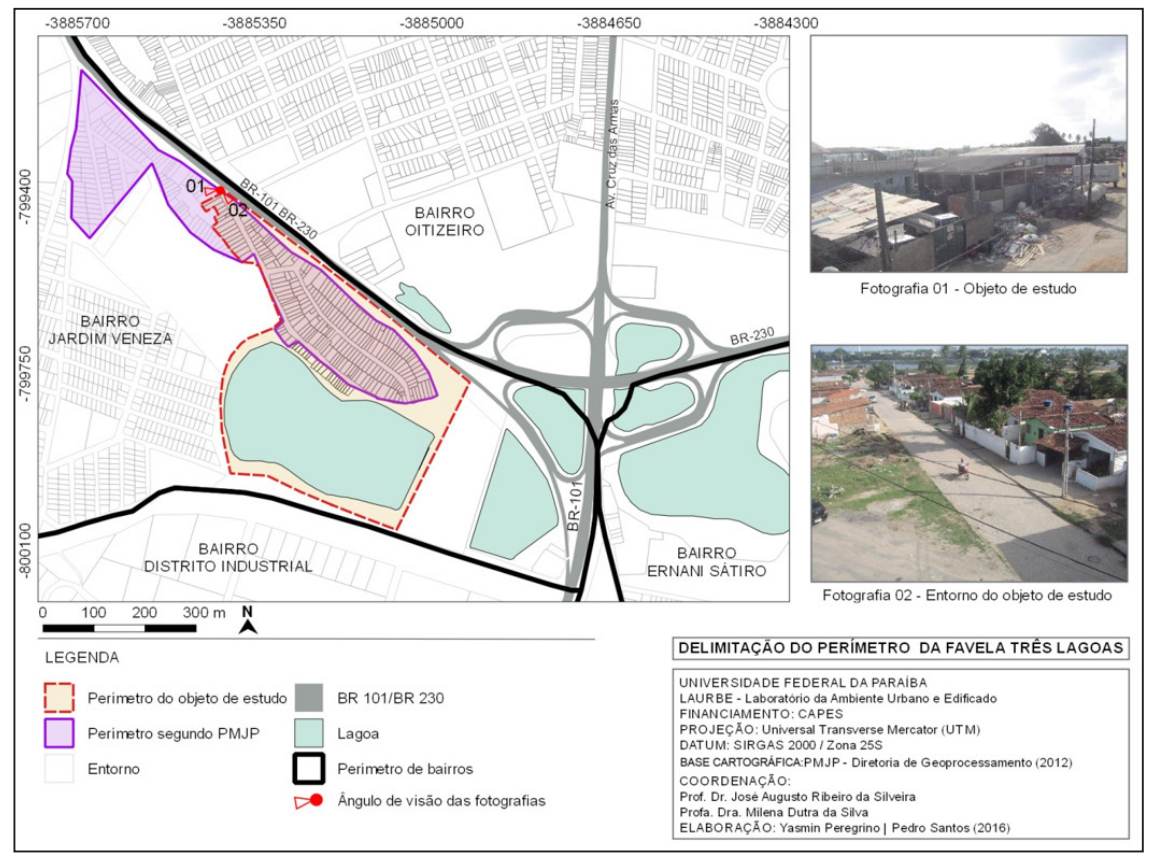

Figura 2 - Mapa de delimitação do perímetro adotado Fonte: Elaborado por Yasmin Peregrino e Pedro Santos (2016). 


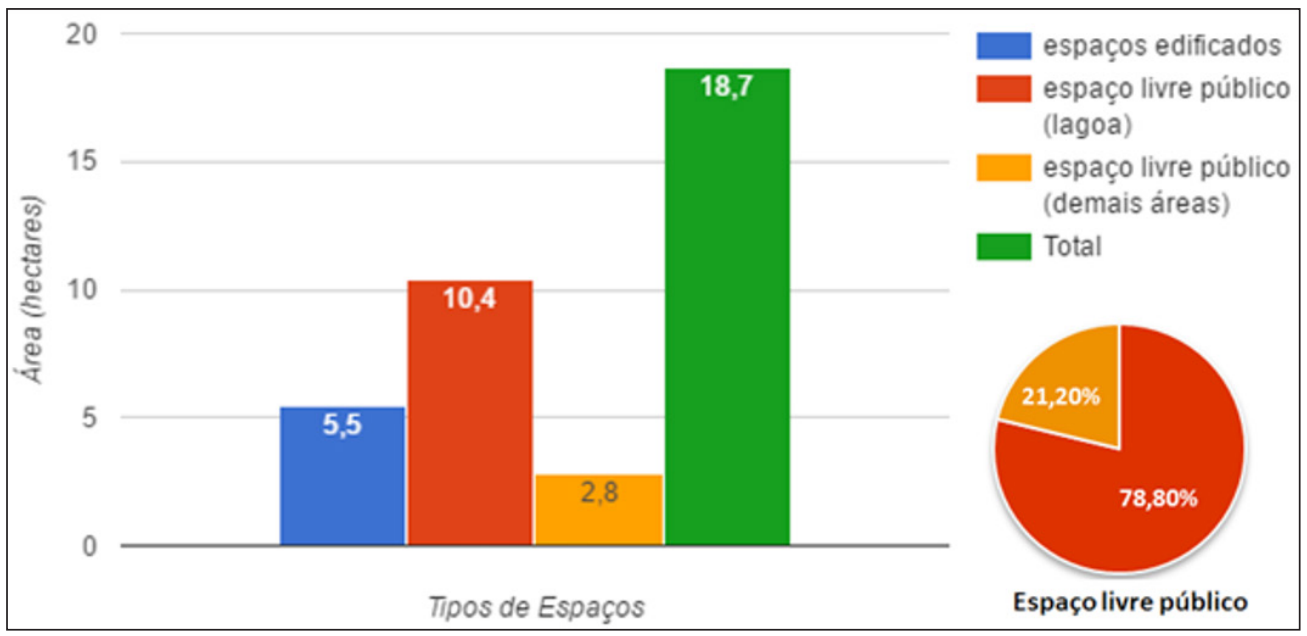

Figura 3 - Ocupação dos Espaços Livres Públicos e edificados de Beira Molhada Fonte: Elaborado pelos autores (2016).

dos lotes), de uso e sua pouca relação socioespacial com a lagoa adjacente e demais espaços públicos, além da dificuldade de acesso para aplicação dos instrumentos de análise. Optou-se também pela incorporação da margem sul da lagoa nas análises, tendo em vista que a tônica deste artigo é o ELP (Figura 2).

Assim, o perímetro adotado totaliza 18,7 ha, dos quais 13,2 ha são espaços livres públicos tratados e/ou acidentais, sendo 10,4 ha destinados à porção da lagoa e seu anel, e 2,8 ha para os demais espaços livres públicos e vias. A predominância das áreas livres sobre as edificadas pode transmitir uma impressão enganosa sobre a publicização dos espaços livres de Beira Molhada, sugerindo que se encontram atendidas as necessidades de lazer e mobilidade de seus residentes. Contudo, essa predominância de ELP se justifica pela presença da lagoa e seu anel urbanizado, que juntos somam 10,4 ha (Figura 3).

Além dessa predominância de ELP, a escolha desse recorte geográfico se justifica por seu atual estado predominante de pacificação, sua relação com as rodovias e com a área de preservação ambiental e sua caracterização como ZEIS ${ }^{10}$, além da parceria com

\footnotetext{
10"Zonas Especiais de Interesse Social são aquelas destinadas primordialmente à produção, manutenção e à recuperação de habitações de interesse social [...]" e compreendem, dentre outros espaços, "[...] terrenos públicos ou particulares ocupados por favelas ou por assentamentos assemelhados, em relação aos quais haja interesse público em se promover a urbanização ou a regularização jurídica da posse da terra [...]" (João Pessoa, 2009, p. 12-13).
}

um projeto social local, o Projeto Segunda Chance ${ }^{11}$, que viabiliza a aplicação das técnicas de pesquisa in loco. Tais fatores permitiram observar diversas problemáticas inerentes à produção do espaço livre público informal, tais como a questão ambiental, morfológica e a relação com a acessibilidade e a mobilidade urbana.

Beira Molhada encontra-se inserida no bairro Jardim Veneza, na fronteira com o bairro Oitizeiro, próximo ao distrito industrial e distante, $8,7 \mathrm{~km}$ do centro da cidade. Considerando a mesoacessibilidade, tomou-se um raio de $500 \mathrm{~m}^{12}$ a partir do perímetro de estudo, sendo possível acessar a pé alguns serviços institucionais públicos, como: Posto de saúde da Família (PSF), creche municipal e estadual, escola estadual (Figura 4).

\footnotetext{
${ }^{11}$ Projeto social voluntário, sem fins lucrativos, com o suporte de igrejas cristãs e apoiado por diferentes áreas do conhecimento (arquitetura, psicopedagogia, educação física, etc.). Atua em Três Lagoas desde 2010, com atividades para crianças, adolescentes e jovens, alcançando pontualmente adultos e idosos. Já foram oferecidas aulas de balé, futsal, reforço escolar, alfabetização de adultos, campeonatos esportivos, recitais de balé e celebrações de datas comemorativas. A maioria das atividades é desenvolvida nas ruas, quadras e demais espaços públicos da própria favela, e embora estejam relacionadas a princípios religiosos, não condicionam a participação nas atividades laicas às programações de cunho religioso.

${ }^{12}$ Aqui, foi utilizada a recomendação de Ferraz \& Torres (2004, p. 110), que sugerem $300 \mathrm{~m}$ a 500 m como distância facilmente caminhável.
} 


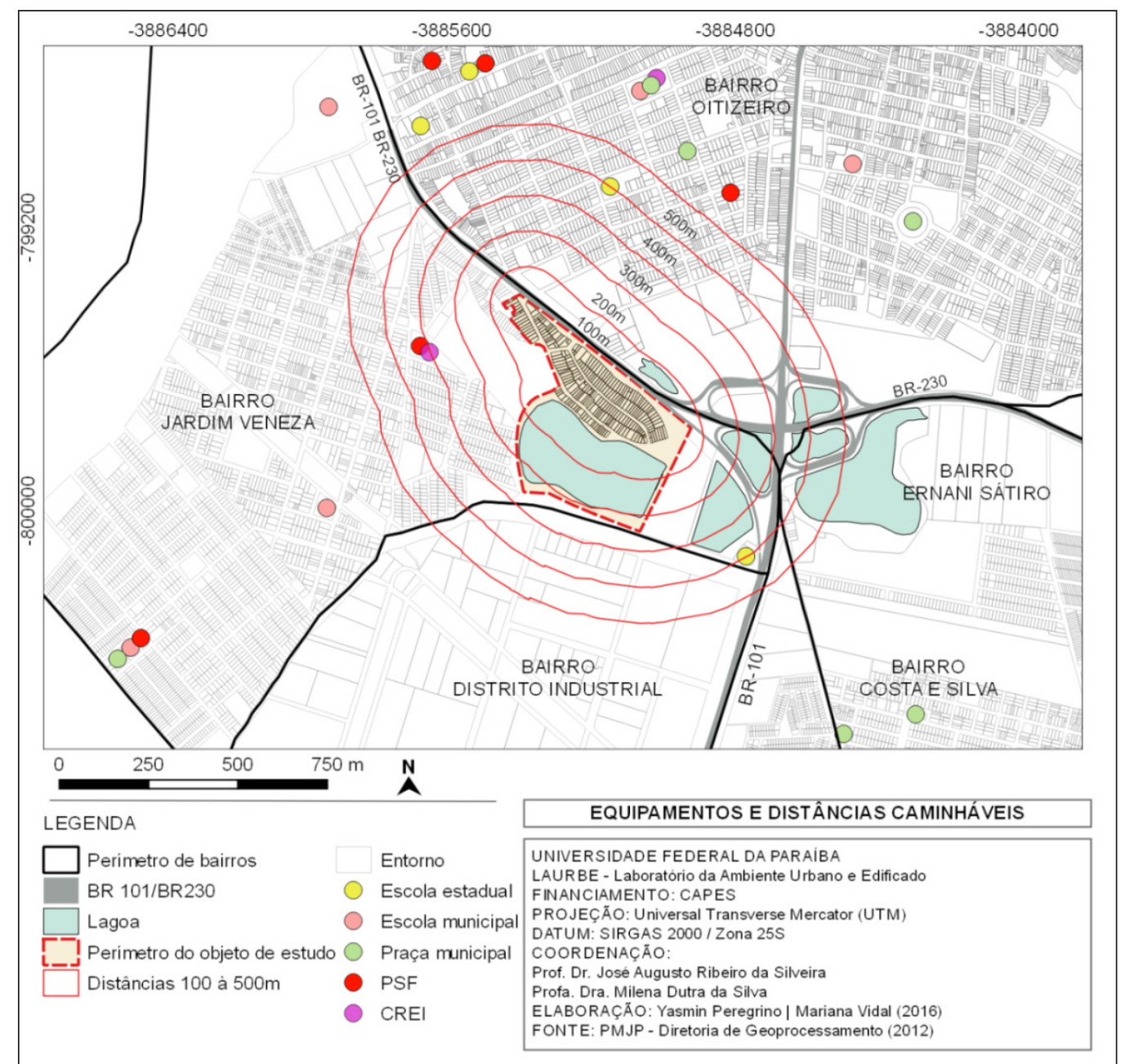

Figura 4 - Mapa de equipamentos e distâncias caminháveis

Fonte: Elaborado por Yasmin Peregrino e Mariana Vidal (2016).

O Açude das Três Lagoas tem grande importância ambiental, pois trata-se de uma área de preservação com potencial contemplativo, de onde se observa o pôr do sol (Figura 5). 0 açude é envolvido por um viaduto que permite o cruzamento da Av. Cruz das Armas com as rodovias BR 101 e 230 e contou com obras referentes à drenagem e infraestrutura urbana no entorno da porção da lagoa que fica adjacente à Beira Molhada, a saber: implantação de jardins, iluminação pública e mobiliário urbano, pavimentação do anel da lagoa e construção de quadras poliesportivas.

Assim, o Açude das Três Lagoas se caracteriza como um conjunto de grande potencial urbanístico e ambiental na escala da cidade, contudo, como o acesso a este se dá predominantemente através das vias da favela, os residentes da parcela formal urbana fazem pouco uso deste bem, representando uma perda

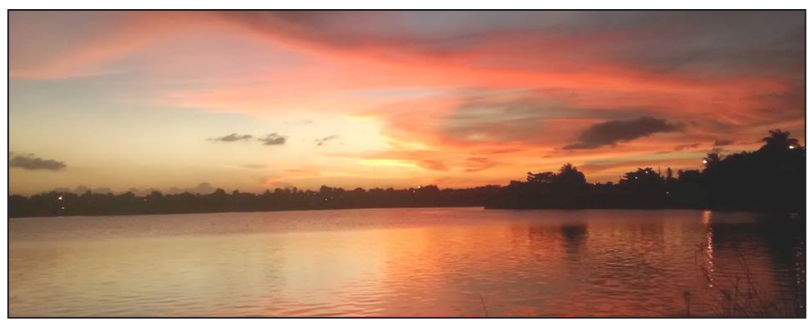

Figura 5 - Pôr do sol em Beira Molhada Fonte: Cedido por moradores (2014).

para a cidade. Soma-se a isso a falta de manutenção da infraestrutura urbana, entre outros fatores que desestimulam sua apropriação, tais como a poluição e os gradis e balizadores, que implantados pela urbanização citada inibem a relação da favela com a lagoa. Em contrapartida, os residentes de Três Lagoas abriram passagens em trechos específicos dos gradis 
para facilitar os acessos mais utilizados, demonstrando que tal necessidade de ir e vir não foi levada em conta no projeto de urbanização (Figura 6a, b, c).

Além disso, a ineficiência quanto à segurança pública contribuiu para que práticas ilícitas vinculadas ao tráfico de drogas degradassem esse ELP e restringissem sua apropriação. Nota-se a restrição na apropriação destes 10,4 ha, que se tornam espaços livres "públicos" planejados de modo a excluir a favela, e apropriados por componentes de sua população para inibir a cidade formal, configurando um ciclo de exclusão e desuso do ELP. Nota-se que, até mesmo os espaços privados edificados se fecham para o espaço público, completando seu esvaziamento, excluindo os "olhos da rua" e suprimindo as "zonas híbridas". A exemplo disso, tem-se o fato de que os lotes imediatamente adjacentes à lagoa passaram a fechar seus acessos a ela e abrir suas frentes apenas para a rua interna à favela, ratificando a lagoa como um espaço não atrativo e inseguro (Figura 7a, b, c).
Contudo, com a ação do Projeto Social Segunda Chance a partir de 2010, percebeu-se a consolidação de um processo de pacificação que foi estabelecido no âmbito social e refletido no urbano, amenizando gradativamente o ciclo de exclusão. A partir de 2012 houve a retomada de práticas sociais positivas no espaço público do entorno da lagoa, com suporte à cultura e lazer (Figura 8).

Tal retomada foi constatada nos mapas mentais aplicados por Peregrino (2014), com 57 pessoas, incluindo moradores e visitantes de 6 a 39 anos, que retrataram o ELP, seus usos, apropriações e necessidades de manutenção. Inúmeros mapas espacializaram as atividades do Projeto Segunda Chance, principalmente as aulas de futsal que ocorrem na quadra pública (Figura 9b). Um dos mapas mentais apontou a necessidade de manutenção de uma das quadras esportivas, ao passo que desenha a outra sendo utilizada, visto ser a adotada e mantida pelo projeto social (Figura 9a). Nota-se, assim, a importância de agentes sociais para reaver o caráter público dos
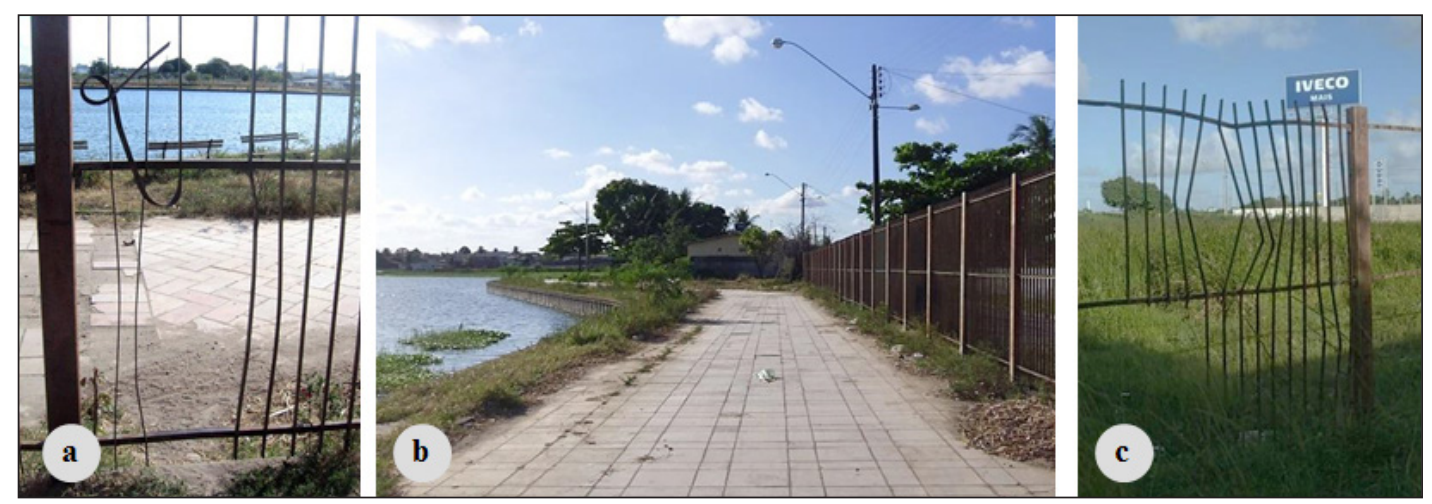

Figura 6 - $(a, b, c)$ Gradis degradados no entorno da lagoa

Fonte: Yasmin Peregrino (2012).
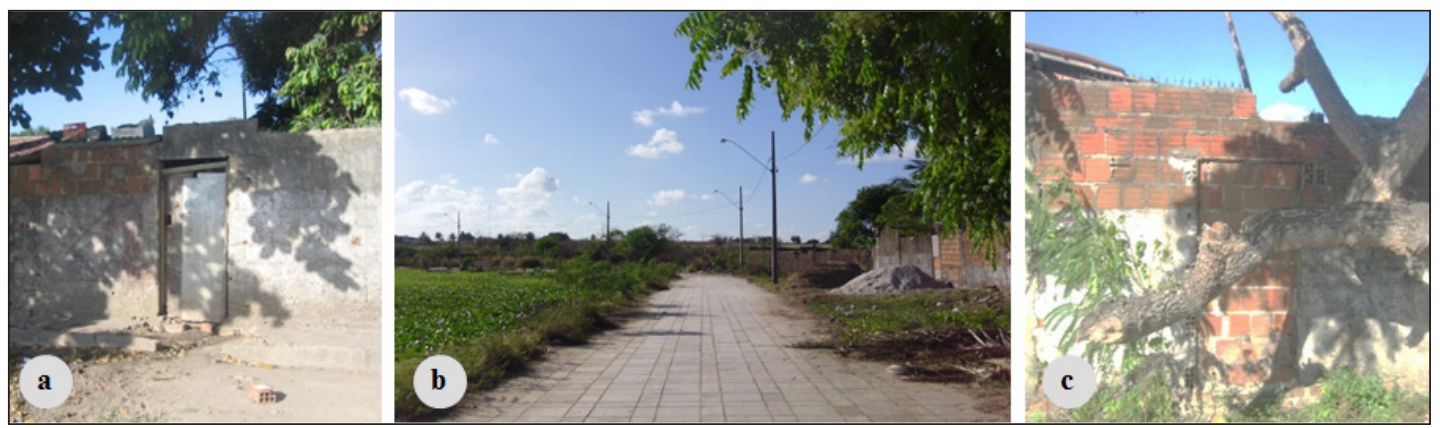

Figura 7 - Lotes com acesso à lagoa fechados Fonte: Yasmin Peregrino (2012). 

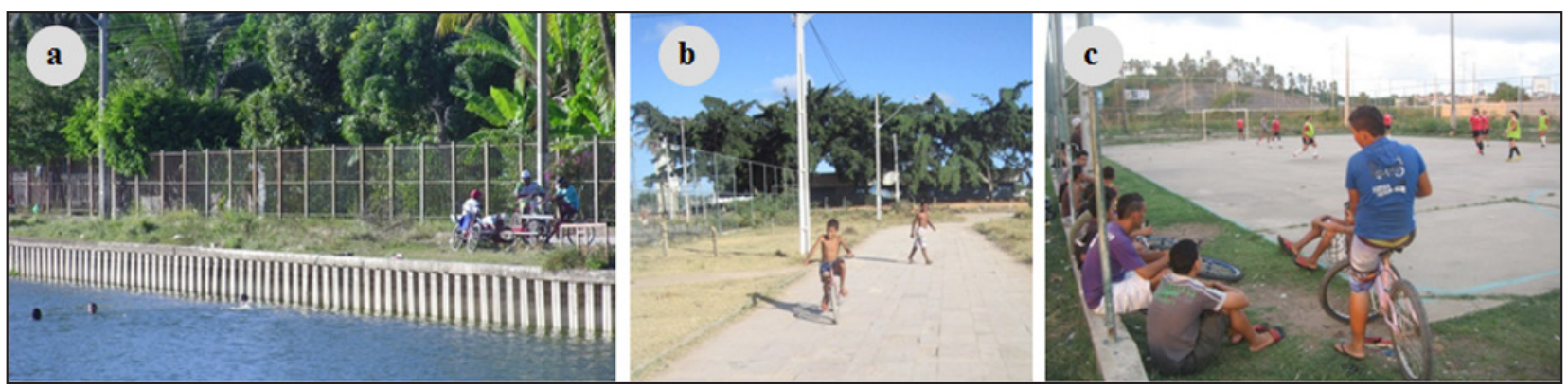

Figura 8 - Reapropriação da lagoa (a) banho, (b) lazer e (c) prática de esportes Fonte: Yasmin Peregrino (2012).

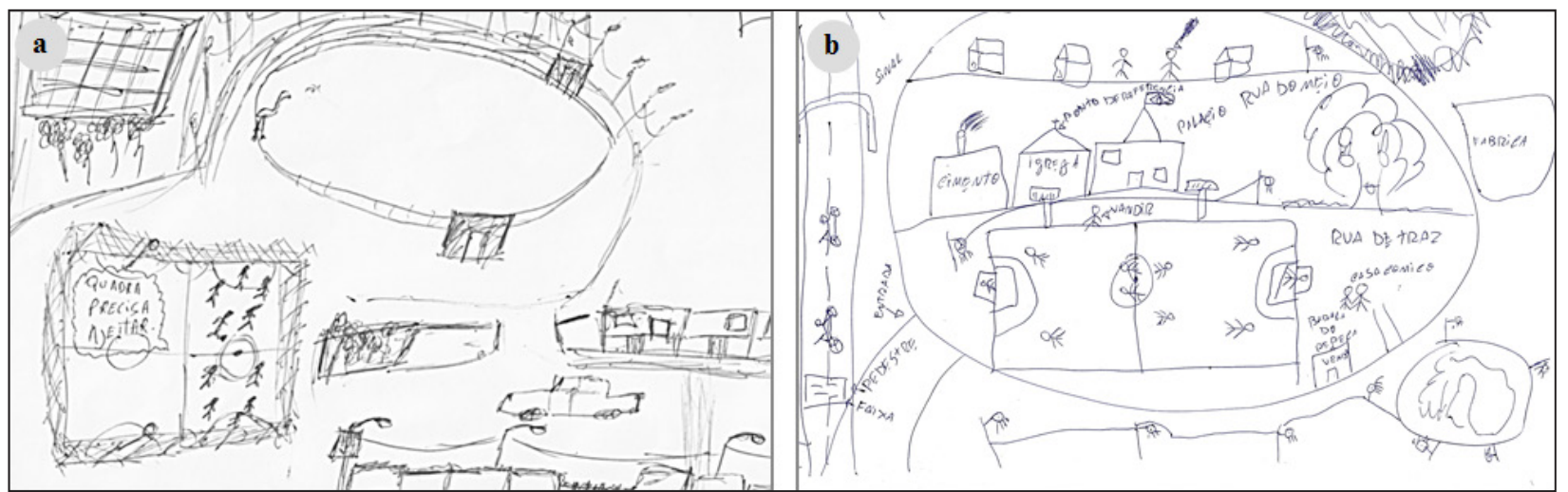

Figura 9 - Trecho de um mapa mental feito por um residente de Beira Molhada, de 14 anos (a) e 12 anos de idade (b) Fonte: Yasmin Peregrino (2014).

espaços livres e mediar o contato da comunidade com a gestão pública.

Nesse processo de retomada de práticas sociais positivas no ELP, ficam evidentes as suas deficiências, tais como a falta da microacessibilidade, ausência de arquibancadas de suporte à quadra esportiva, sinalização, mobiliário de permanência, iluminação pública, e espaços de suporte às apresentações culturais. Contudo, a criatividade dos usuários deste espaço tem levado a adaptações que anunciam as suas necessidades, a exemplo do recital de balé promovido pelo projeto social, em 2013, na quadra esportiva da favela (Figura 10). Embora com êxito, tal apresentação foi prejudicada pela falta de suporte técnico, lumínico e sonoro, e de acomodação para a plateia, além do piso cimentício da quadra, que não atende às exigências de atrito e aderência, prejudicando a performance e o figurino.

Desse modo, com a ausência da atuação do poder público em manter e fiscalizar o espaço, e o insurgente anseio de reapropriação do ELP, os usuários passaram a improvisar soluções para as consequências da degradação. Para isso, utilizam-se da bricolagem como "[...] reciclagem arquitetural, sobretudo aleatória, que nasce da fragmentação de antigas arquiteturas [...]" (Jacques, 2011, p. 29), fazendo uso de recursos naturais e resíduos da construção civil formal (Figura 11).

A falta de assistência técnica na construção dos espaços privados também influencia diretamente na relação ambiental e com o espaço livre público, visto que a limitação dos materiais bricolados e a improvisação dos métodos construtivos e de saneamento, comumente, geram soluções que prejudicam o equilíbrio ambiental. Um exemplo disso está presente na maioria das ligações irregulares de esgotamento sanitário das casas da favela Beira Molhada, que despejam os resíduos sem nenhum tratamento na lagoa (Figura 12). Assim, o ELP de Três Lagoas e suas possibilidades de apropriação encontram-se fortemente relacionados com o risco ambiental e o social.

Além das implicações da falta de manutenção da infraestrutura e do meio ambiente, observa-se que a falta de sinalização e fiscalização no ELP implicam conflitos de mobilidade entre modais. No anel 

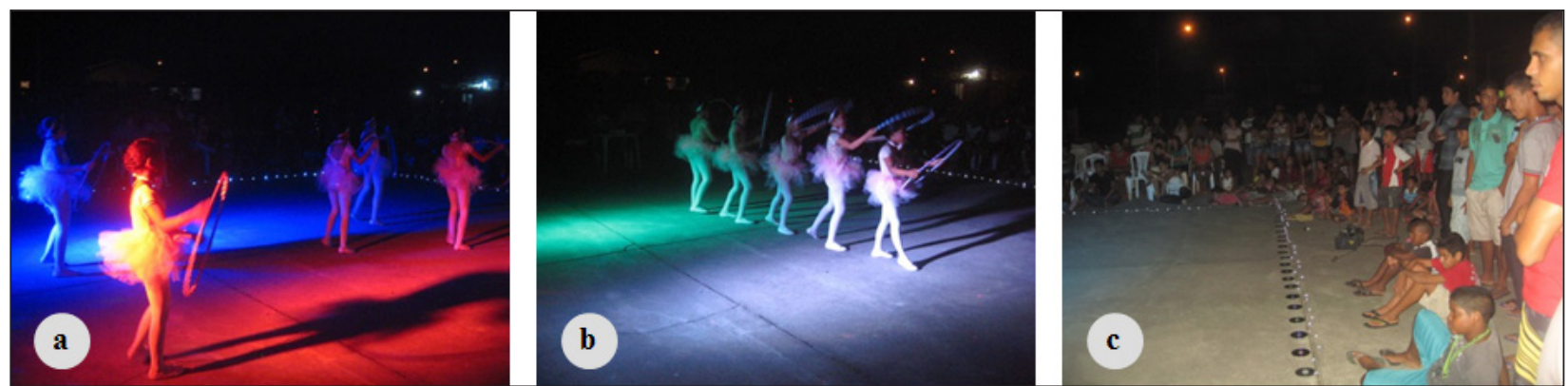

Figura 10 - Uso da quadra esportiva para apresentações culturais Fonte: Yasmin Peregrino (2013).
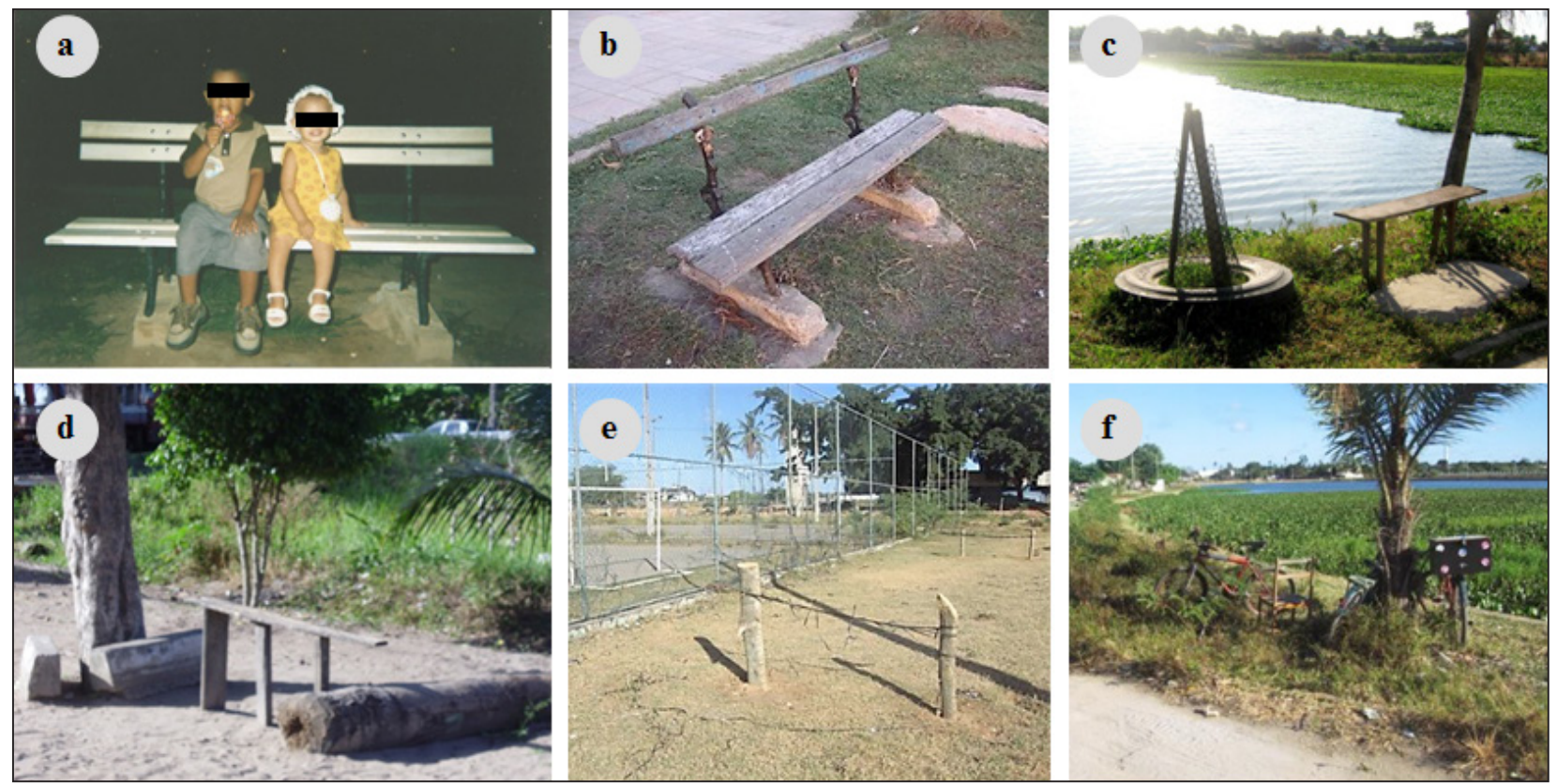

Figura 11 - (a) Mobiliário no ano da entrega; (b) Mobiliário original degradado; (c-d) Bancos improvisados pelos moradores através de bricolagem; (e) Traves improvisadas para jogos esportivos; (f) Paraciclo improvisado junto à vegetação Fonte: (a) Cedido por residentes (2005); (b-f) Yasmin Peregrino (2012).

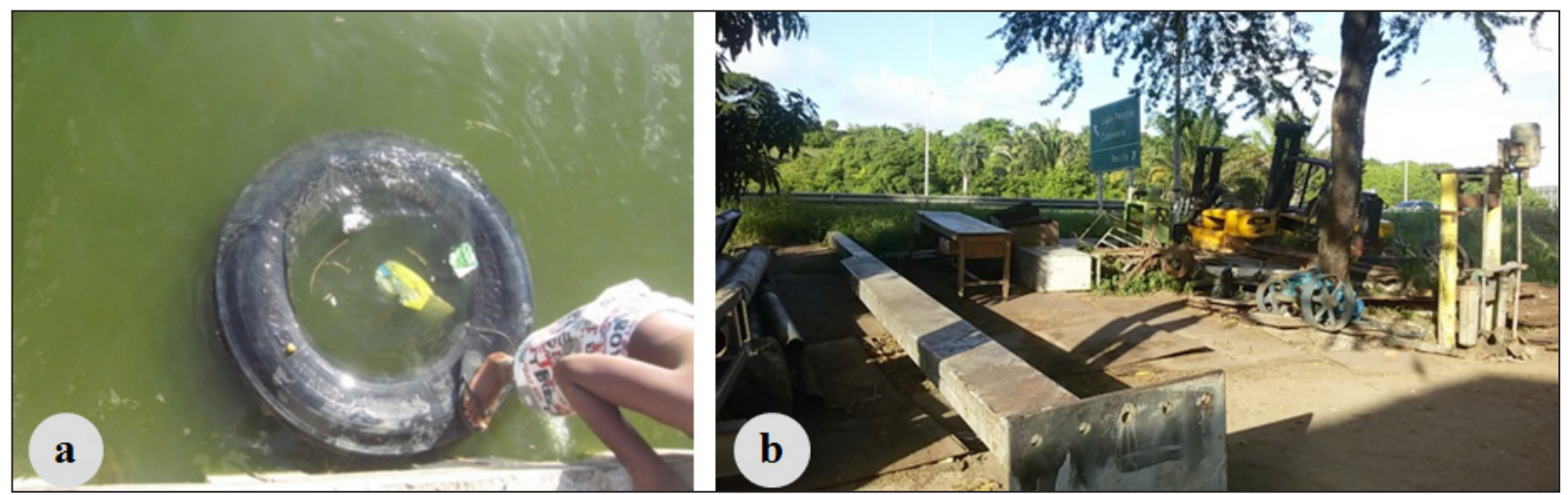

Figura 12 - (a) Resíduos poluindo a lagoa; (b) Entulhos acumulados no ELP Fonte: Yasmin Peregrino (a) 2012 e (b) 2014. 
pavimentado da lagoa, por exemplo, não há sinalização indicando o uso exclusivo para pedestres, e supõe-se que assim deva ser, dado seu dimensionamento, pavimentação e locação de mobiliários. Contudo, é recorrente a presença de carros, motos, ciclistas e até cavalos (Figura 13).

Seu traçado, embora não seja planejado e executado por profissionais habilitados, não é labiríntico e se aproxima das configurações morfológicas dos loteamentos irregulares. Contudo, através de cartografias, é possível constatar a presença de desvios e inflexões, dada a limitação dos métodos construtivos, equipamentos, capacitação técnica e necessidade de adaptação ao sítio geográfico. Embora a percepção dessa sinuosidade seja possível ao analisar cartografias, na escala do observador predomina a linearidade. Isso pode ser constatado nos mapas mentais, onde o ELP representado pelas vias foi predominantemente desenhado pelos participantes como linear e distendido, partindo da lagoa como marco espacial, reforçando o espaço público como marco e suporte para orientabilidade (Figura 14).

Além disso, é notória a falta de integração da malha viária de Três Lagoas com seu entorno, no qual se observa a presença de vias de grande importância para a cidade, tais como a Av. Cruz das Armas e as rodovias BR 101/BR 230. No âmbito dos veículos motorizados, os dois únicos acessos "formais" para a favela não contam com sinalização, pavimentação, faixa de desaceleração, iluminação, ou ordenação de fluxos

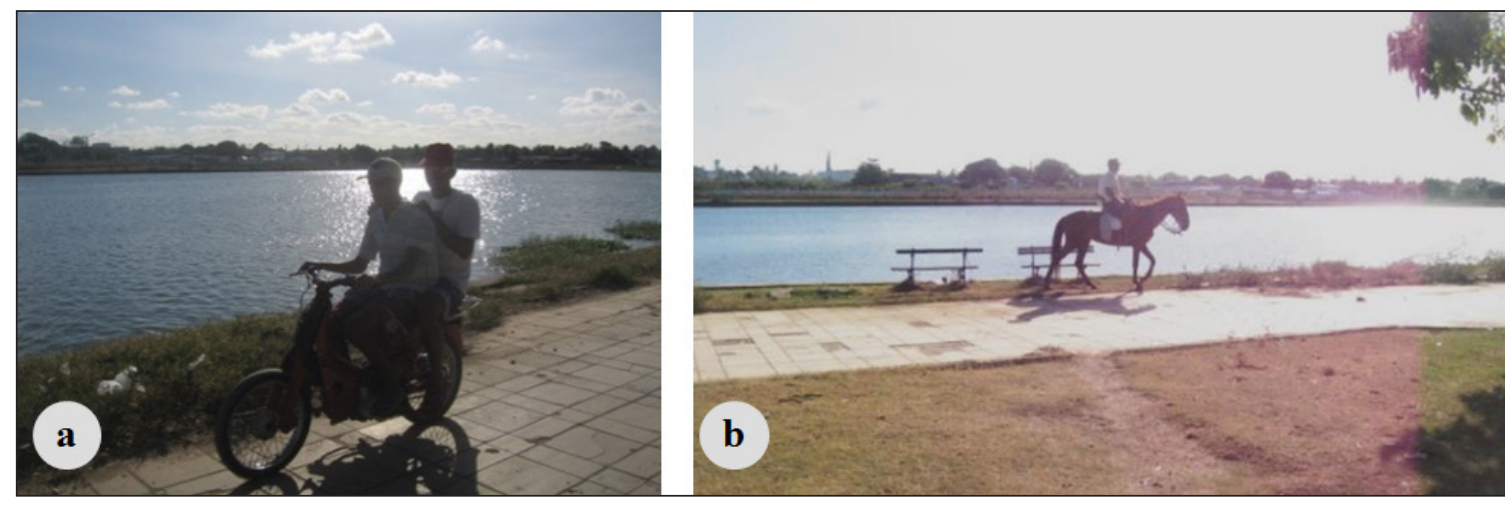

Figura 13 - Conflito de modais no entorno da lagoa Fonte: Yasmin Peregrino (2012).

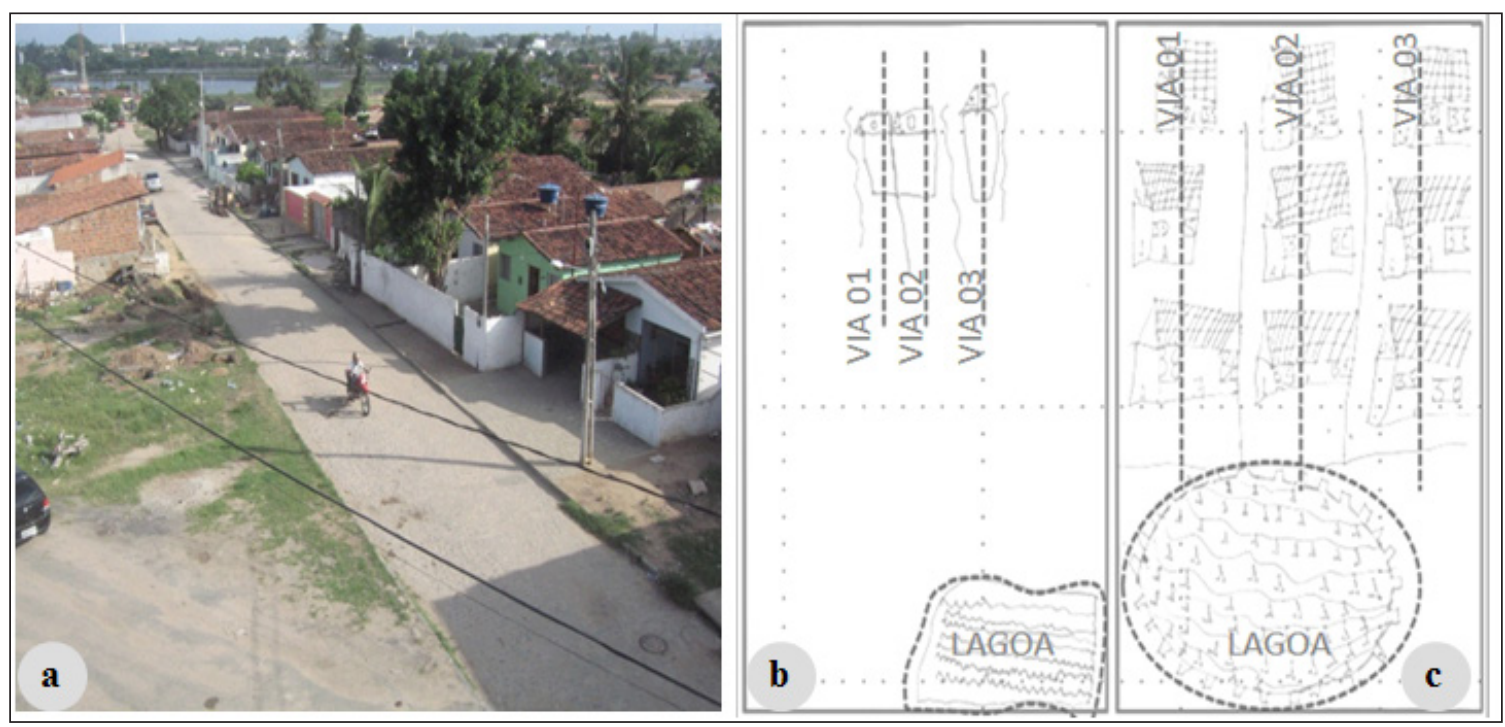

Figura 14 - (a) Rua interna de Beira Molhada; Mapas mentais de moradores de 6 (b) e 9 anos (c) Fonte: Peregrino (2014), p. 53 (a) e p. 85 (b-c). 
(Figura 15). No âmbito do pedestre, é dificultado o acesso ao entorno da favela, devido à estrutura viária disponível, tendo em vista o fluxo intenso, muretas de divisão de faixas de rolamento, inexistência de passeio público. Assim, como possibilidade concreta de deslocamento pedonal restam o acesso ao próprio bairro Jardim Veneza e a passarela que permite transpor a sobreposição das rodovias BR 101/BR 230, como rota em direção ao bairro Oitizeiro e aos demais bairros adjacentes. Contudo, são recorrentes as reclamações dos moradores da favela, que alegam não fazer uso da passarela em determinados dias e horários por causa da falta de segurança pública e percurso extenso, preferindo atravessar as rodovias, implicando acidentes com vítimas fatais (Figura 15).

No tocante ao dimensionamento e pavimentação, as vias em sua maioria atendem parcialmente às exigências da legislação vigente. 0 leito carroçável é predominantemente pavimentado em paralelepípedo e apresenta em torno de $5 \mathrm{~m}$ de largura, enquanto o código de urbanismo do município exige um mínimo de $6 \mathrm{~m}$, e a maioria das calçadas é também insuficiente quanto à dimensão, sinalização e pavimentação. Em relação aos serviços básicos, Beira Molhada tem coleta de lixo e abastecimento legalizado através de rede de água e energia para a maioria das habitações. A ausência do esgotamento sanitário, associada ao funcionamento insuficiente da drenagem pluvial, eleva riscos ambientais que se intensificam com os alagamentos em épocas de chuvas, gerando insalubridade, mas não impedindo a apropriação do espaço livre público (Figura 16).

As deficiências quanto à infraestrutura não necessariamente implicam desuso ou falta de vitalidade no espaço público de Três Lagoas, visto que nas vias se desenvolvem atividades cotidianas que, na cidade formal, são internas ao lote e aos espaços coletivos. 0 reduzido fluxo e baixa velocidade de veículos corroboram para tornar esses espaços mais próximos à escala humana, incentivando sua apropriação (Figura 17).

Nota-se que são restritas as exigências quanto à privacidade entre as unidades habitacionais, e entre essas e o ELP, pois a necessidade de adensamento
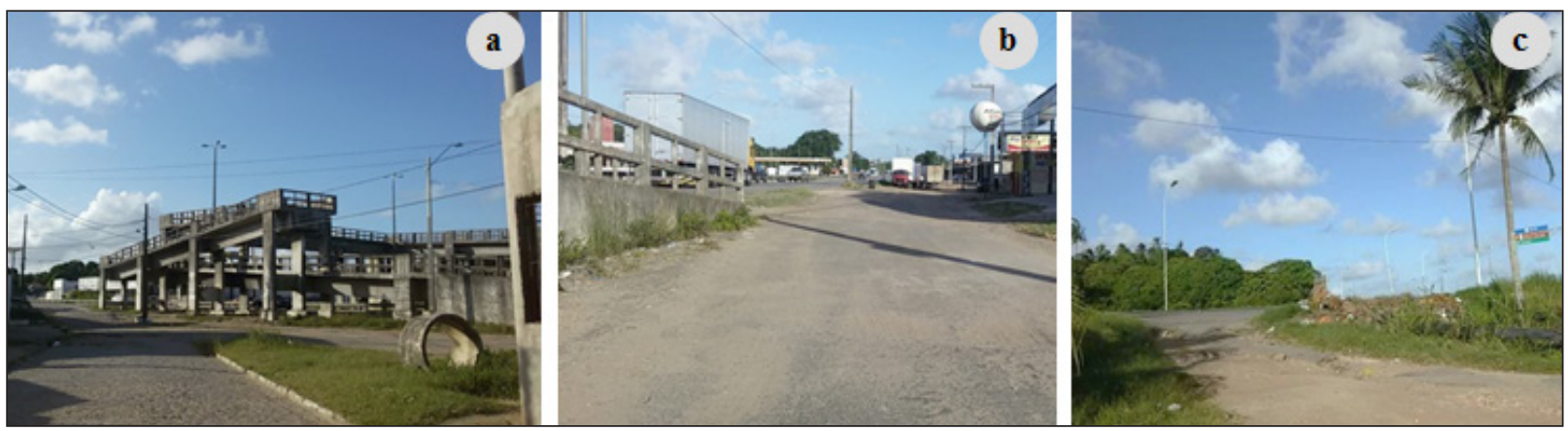

Figura 15 - (a, b) Passarela para pedestres sobre as rodovias; (c) Um dos acessos a Três Lagoas partindo da rodovia Fonte: Yasmin Peregrino (2016).
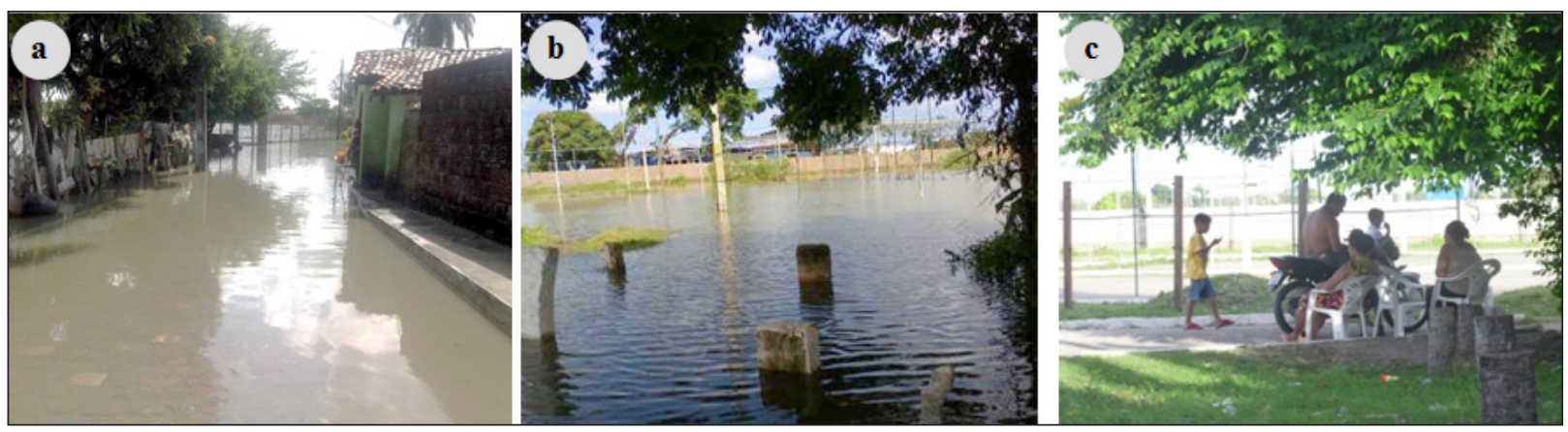

Figura 16 - (a) Rua interna de Beira Molhada alagada; (b) ELP de Três Lagoas alagado; (c) Vitalidade do ELP de Beira Molhada Fonte: Cedida por moradores locais (2013). 
implica configurações arquitetônicas e urbanísticas que confrontam a individualidade, a exemplo de casas sem recuo e esquadrias das residências abrindo diretamente para a rua, permitindo que ao caminhar nas vias internas à favela, o pedestre tenha comunicação direta com os moradores dentro de suas casas. A relação entre a via pública e o lote é constante e contribui nitidamente para a vitalidade do ELP local (Figura 18).

Soma-se a isso a baixa renda, que dificulta o acesso a outros tipos de espaços para lazer, como praças e a orla marítima da cidade, principalmente pelo alto custo com mobilidade e dificultada macroacessibilidade. Desse modo, o espaço livre público interno à favela é visto como oportunidade às alternativas de lazer, contribuindo para a vitalidade e inibindo práticas ilícitas (Figura 19).

0 caso de Beira Molhada demonstra que, a partir de iniciativas de agentes sociais, como menciona Burdett (2012), é possível fortalecer o sentido de comunidade ativando o espaço público, através de pequenas intervenções urbanas, com ações concretas

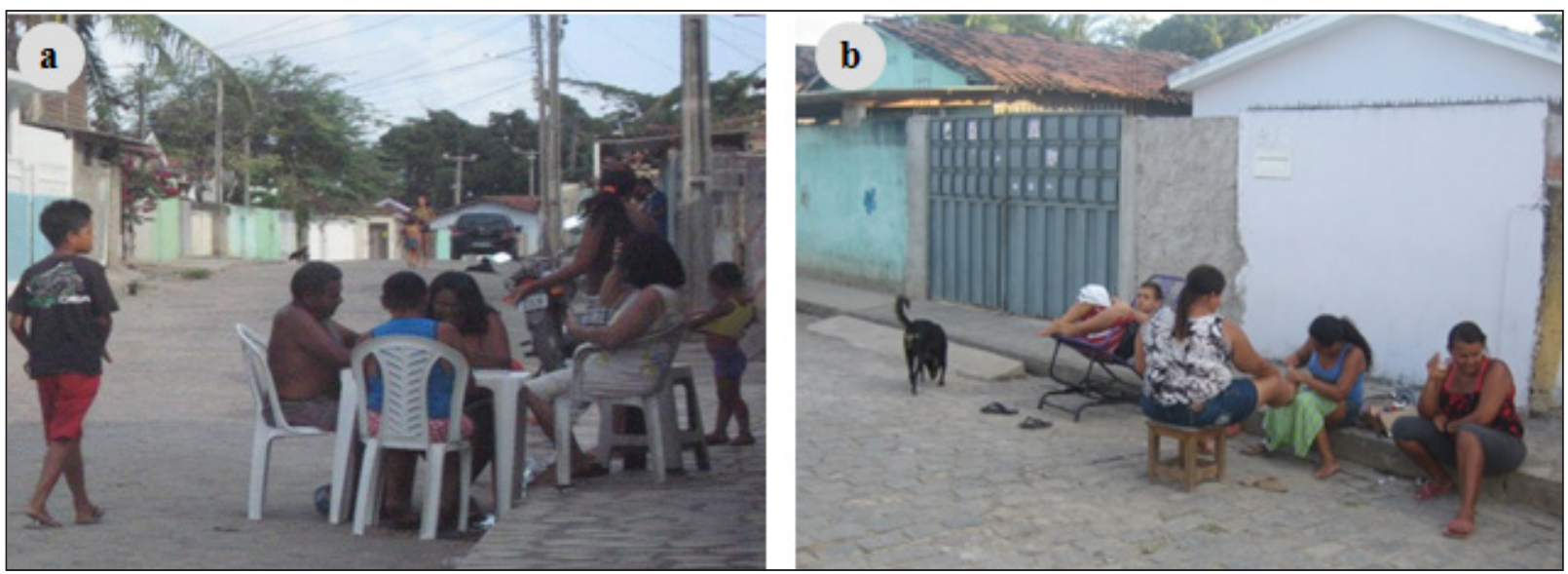

Figura 17 - Reunião para jogos (a) e manicure (b) na calcada e leito carroçável de uma via interna de Beira Molhada Fonte: Yasmin Peregrino (2012).
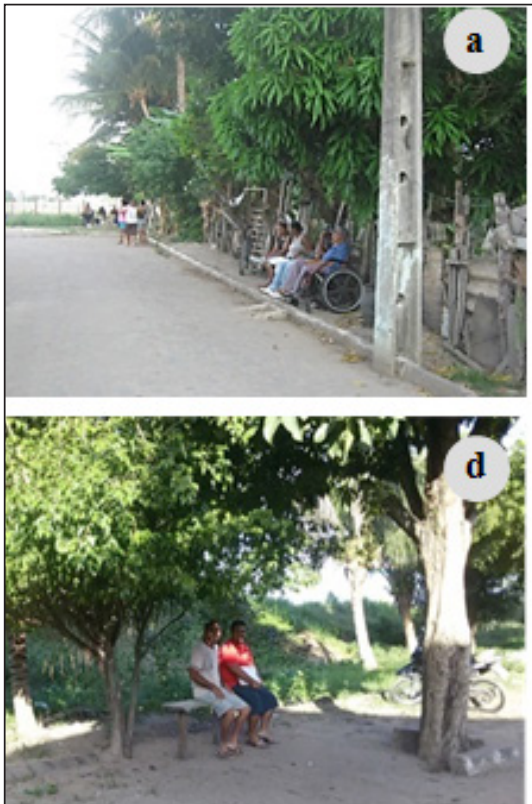
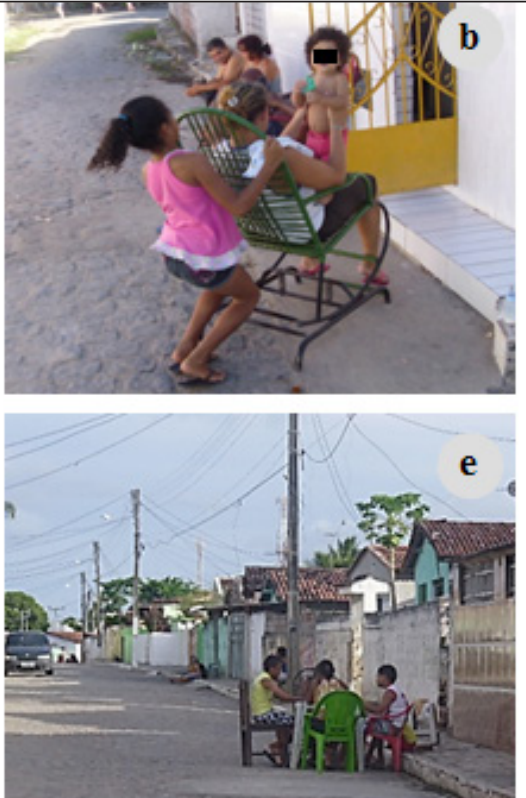
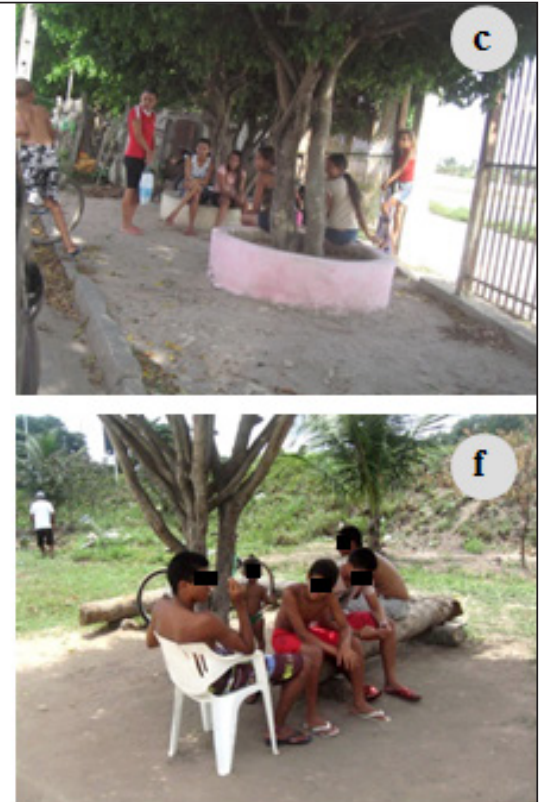

Figura 18 - Vitalidade do ELP de Beira Molhada Fonte: Yasmin Peregrino (2012). 


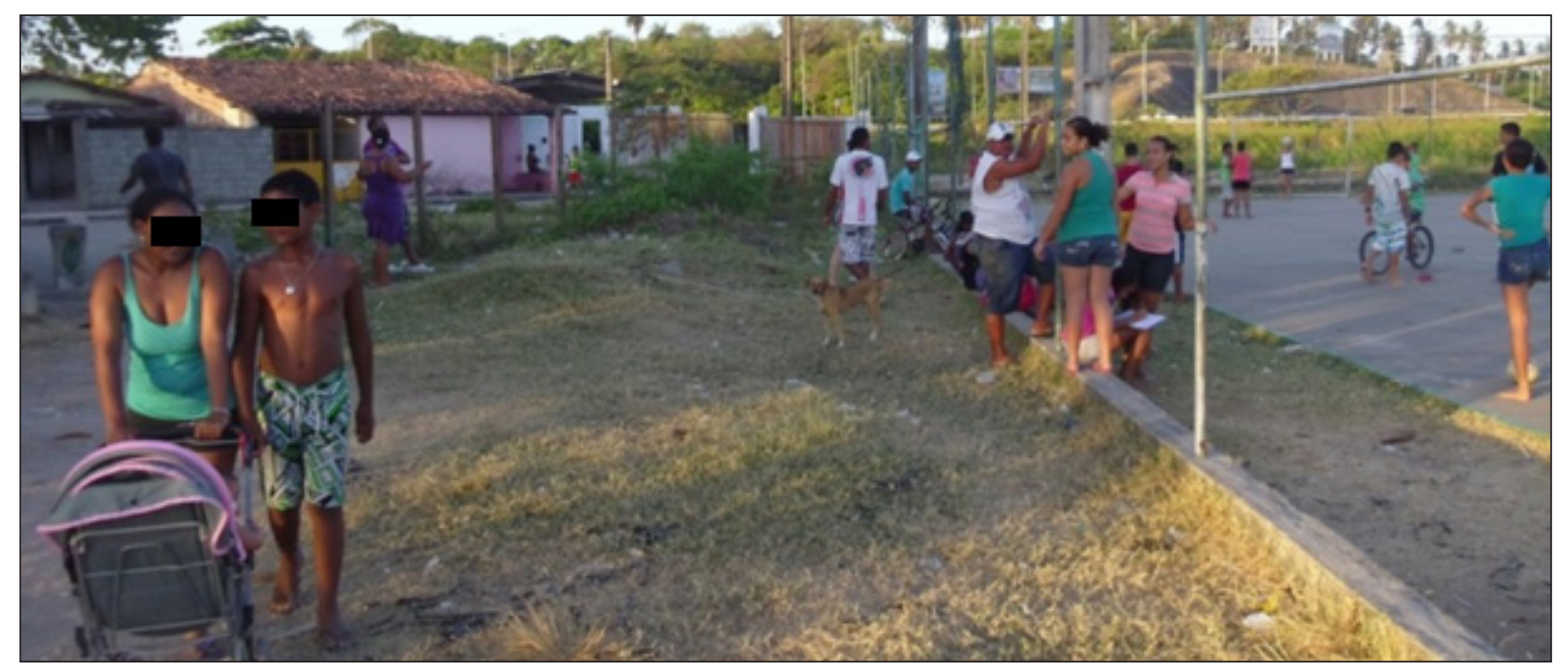

Figura 19 - Vitalidade e diversidade do ELP de Beira Molhada

Fonte: Yasmin Peregrino (2012).

tais como mobiliário, ou efêmeras como apresentações culturais e esportivas. Infelizmente, são ainda poucas as iniciativas como essa que recebem apoio, financeiro ou humano, das políticas públicas.

Atualmente, o Projeto Segunda Chance, por questões financeiras e logísticas, suspendeu algumas atividades esportivas e culturais, já sendo possível identificar o enfraquecimento das conquistas socioespaciais alcançadas, como a diminuição do uso e manutenção dos ELPs e até retorno de alguns residentes às práticas ilícitas. Vale ressaltar que tal "retrocesso" não atribui culpa ao projeto social, ao contrário, só ressalta que sua atuação é extremamente válida.

Como visto, não se realiza transformação urbana e social em assentamentos precários de maneira rápida e definitiva, pois o processo é dinâmico e implica lidar com desafios físicos, socioeconômicos e culturais, tanto em relação às próprias comunidades quanto aos agentes do poder público que precisam retomar nova consciência de como lidar com esse universo.

\section{Considerações finais}

A resiliência observável nos residentes dos espaços informais e em sua dinâmica de autoconstrução pode ser vista como uma estratégia de direito à cidade, ratificando a necessidade da integração socioespacial de Beira Molhada e demais assentamentos informais brasileiros, visto que, segundo a visão lefebvriana, a "sociedade urbana" deve ser o lócus das diferenças e tolerâncias. Para isso, é preciso interromper o ciclo excludente no qual a sociedade formal sustenta barreiras físicas e atitudinais que segregam e conformam espaços conflituosos e vazios de vida.

Entretanto, ao passo que a administração pública tarda em atender a essa necessidade de integração, as estratégias coletivas locais de superação resistem, promovidas por agentes sociais diversos, em prol do acesso à cidade e seus serviços. A dificuldade de implantar master plans que consigam atender às particularidades locais tem dado ênfase à atuação em escala local através de intervenções ditas acupunturais que promovem ações de baixo custo, facilmente readaptáveis, baseando-se na percepção das potencialidades e necessidades específicas de cada localidade.

Um exemplo disso é a atuação do Projeto Segunda Chance, em Beira Molhada, que promoveu ações pontuais locais com considerável repercussão em Três Lagoas, tais como o incentivo ao uso e manutenção dos espaços públicos da favela, que adquiriram vitalidade com a diminuição da degradação, implicando restaurações improvisadas através da bricolagem. Com isso, o espaço público, aos poucos, teve seu caráter de marco retomado, contribuindo para orientabilidade e para a interação social.

Contudo, a falta de assistência técnica em tais improvisos feitos pelos residentes tem acarretado na intensificação do risco ambiental, visto que, por serem 
leigos, acabam não percebendo o quanto impactam o meio ambiente, pois mesmo despejando os esgotos na lagoa, nela também tomam banho e pescam. É, portanto, necessária a conscientização ambiental associada ao acesso à assistência técnica gratuita e a reformas urbanas direcionadas ao problema. Contudo, mesmo diante do risco ambiental, os mapas mentais aplicados em Três Lagoas mostraram que a união da bricolagem, da reapropriação do ELP e da vitalidade das zonas híbridas reforçou a identidade do espaço público.

Percebeu-se também que a falta de integração entre Beira Molhada e o tecido formal da cidade dá-se, em parte, pela consolidação de sua identidade enquanto local de violência urbana, consequente do tráfico de drogas que prevalecia principalmente antes da atuação do Projeto Segunda Chance. Entretanto, acredita-se que ações socioculturais como as realizadas pelo projeto social possibilitaram novas práticas sociais, contribuindo para uma nova identidade de Beira Molhada e estabelecimento de uma relação entre o formal e o informal com ganhos socioespaciais para a cidade como um todo. Essa integração é fundamental para ambas as partes, visto que a informalidade precisa ter direito à cidade e pode contribuir com lições sobre a retomada do espaço público mesmo diante das adversidades.

A questão não é incentivar o uso indiscriminado do espaço público sem que sejam exigidas qualidade e segurança. Na verdade, espera-se que a compreensão de que se fechando nos lotes os problemas relativos ao ELP não são resolvidos, mas sim postergados e até potencializados. Em vez disso é necessário abandonar a ideia de que o ELP é lugar de ninguém, mas sim tratá-lo como pertencente a todos, pois “[...] a cidade não seria necessária se os habitantes se limitassem à convivência na vida privada [...]" (Jacobs, 2011, p. 61).

\section{Referências}

Burdett, R. (2012). Designing urban democracy: mapping scales of urban identity. Public Culture, 25(2). Recuperado em 12 de janeiro de 2014, de http://publicculture.org/articles/view/25/2/ designing-urban-democracy-mapping-scales-of-urban-identity Conselho Regional de Engenharia e Agronomia do Paraná - CREA-PR. (2011). Mobilidade Urbana. Catálogos Técnicos. Apucarana: CREA-PR. Recuperado em 12 de janeiro de 2014, de http://www.crea-pr.org.br/index.php?option=com_ph ocadownload \&view=category\&id=37: cadernos-tecnicos

Custódio, V., Campos, A. C. M. de A., Macedo, S. S., \& Queiroga, E. F. (2013). Sistemas de espaços livres e forma urbana: algumas reflexões. In Anais do XV Encontros Nacionais da ANPUR (16 p.) Recife: ANPUR. Recuperado em 20 de outubro de 2014, de http://unuhospedagem.com.br/revista/rbeur/ index.php/anais/article/viewFile/4429/4298

DaMatta, R. (1997). A casa \& a rua (5a ed). Rio de Janeiro: Rocco.

Davis, M. (2006). Planeta Favela. São Paulo: Boitempo.

Dixon, C. (2014). A importância dos espaços públicos: uma introdução. Rio de Janeiro: Rio on watch. Recuperado em 18 de dezembro de 2014, de http://rioonwatch.org. $\mathrm{br} / \mathrm{p}=10766$

Ferraz, A. C., \& Torres, I. G. (2004). Transporte Público Urbano. São Carlos: RiMa.

Fioravante, L. M. (2013). Reflexões sobre o "direito à cidade" em Henri Lefebvre: obstáculos e superações. Revista Movimentos Sociais e Dinâmicas Espaciais, 2(2), 173-184.

Fontes, N., \& Shimbo, I. (2003). Análise de Indicadores para Gestão e Planejamento dos Espaços Livres Púbicos de Lazer: Município de Jaboticabal. In: Anais do X Encontro Nacional da ANPUR (p. 1-16). Belo Horizonte: ANPUR.

Gehl, J. (2014). Cidades para pessoas. São Paulo: Perspectiva. Jacobs, J. (2011). Morte e vida de grandes cidades (3a ed). São Paulo: Martins Fontes.

Jacques, P. B. (2011). Estética da ginga: A arquitetura das favelas através da obra de Hélio Oiticica (4a ed). Rio de Janeiro: Casa da Palavra.

João Pessoa. Prefeitura. (2009). Decreto n. $\stackrel{0}{6.499}$, de 20 de março de 2009. Consolida a Lei Complementar n. 054 - Plano Diretor 2009. João Pessoa: Prefeitura Municipal. Recuperado em 10, abril de 2014, de http://www.joaopessoa.pb.gov.br

Karssenberg, H., Laven, J., Glaser, M., \& Hoff, M. V. (Eds.) (2015). A cidade ao nível dos olhos: lições para os plinths. Porto Alegre: ediPUCRS.

Lefebvre, H. (2004). A revolução urbana. Belo Horizonte: Humanitas.

Lefebvre, H. (2006). O direito à cidade. São Paulo: Centauro. 
Leite, M. A. F. P. (2011). Um sistema de espaços livres para São Paulo. Estudos Avançados, 75(25), 159-174. http:// dx.doi.org/10.1590/S0103-40142011000100011.

Lerner, J. (2003). Acupuntura urbana. São Paulo: Record.

Macedo, S. S., \& Custódio, V. (2009). Sistema de espaços livres da cidade contemporânea brasileira e a esfera de vida pública - considerações preliminares. São Paulo: IEB. Recuperado em 12 de março de 2013, de http://jornalggn.com.br/sites/ default/files/documentos/5156_custodio_vanderli.doc

Magnoli, M. (2006). Em busca de "Outros" espaços livres de edificação. Revista Paisagem Ambiente: Ensaios, 21(21), 141-174. http://dx.doi.org/10.11606/issn.2359-5361. v0i21p141-173.

Medeiros, V. (2014). Urbis Brasilae: o labirinto das cidades brasileiras. Brasília: Edu-UnB.

Organização das Nações Unidas - ONU, \& Programa das Nações Unidas para o Desenvolvimento - PNDU. (2014). Relatório do Desenvolvimento Urbano 2014: sustentar o progresso humano: reduzir as vulnerabilidades e reforçar a resiliência. New York: PNDU. Recuperado em 16 de junho de 2015, de http://www.pnud.org.br/arquivos/ RDH2014pt.pdf

Panerai, P. (1994). 0 retorno à cidade: o espaço público como desafio do projeto urbano. Revista Projeto, 173, 78-82.

Peregrino, Y. R. (2014). Diagnóstico sócioespacial de Beira Molhada - Três Lagoas - João Pessoa (trabalho final de graduação). Curso de Arquitetura e Urbanismo, Universidade Federal da Paraíba, João Pessoa.
Pizzol, K. M. S. A. (2005). Uso e apropriação dos espaços livres públicos e informais de uma área urbana em João Pessoa - PB (dissertação de mestrado). Programa de Pós-graduação em Desenvolvimento e Meio Ambiente, Universidade Federal da Paraíba, João Pessoa.

Queiroga, E. F. (2011). Sistemas de espaços livres e esfera pública em metrópoles brasileiras. Resgate, 19(21), 25-35.

Santos, M. (1985). Espaço e método. São Paulo: Studio Nobel.

Silva, J. S., Barbosa, J. L., Biteti, M. O., \& Fernandes, F. L. (Orgs.). (2009). O que é favela, afinal? Rio de Janeiro: Observatório de Favelas do Rio de Janeiro. Recuperado em 21 de março de 2014, de http://observatoriodefavelas. org.br/wp-content/uploads/2013/09/o-que-\%C3\%A9favela-afinal.pdf

Silveira, J. A. R., \& Lapa, T. A., \& Ribeiro, E. L. (2007). Percursos e processo de evolução urbana: uma análise dos deslocamentos e da segregação na cidade. Arquitextos Vitruvius, 8. Recuperado em 10 de abril de 2014, de http:// www.vitruvius.com.br/revistas/read/arquitextos/08.090/191

Sola-Morales, M. (2008). A matter of things. Rotterdam: NAI.

Vasconcelos, P. A. (2004). A aplicação do conceito de segregação residencial ao contexto brasileiro na longa duração. Cidades, 1(2), 259-274. Recuperado em 10 de fevereiro de 2016, de http://revista.fct.unesp.br/index. php/revistacidades/article/viewFile/478/508

Recebido: Ago. 15, 2016

Aprovado: Set. 22, 2016 